Conservation Biology, Volume 18, Number 6 December 2004, 1645-1650

doi: 10.1111/j.1523-1739.2004.00122.x

Copyright (C) Blackwell Publishing 2006

The definitive version is available at www.blackwell-synergy.com

\title{
Damage to Cauliflower Coral by Monofilament Fishing Lines in Hawaii
}

\section{KAZUE ASOH, TOMOKO YOSHIKAWA, RANDALL KOSAKI, AND ELIZABETH A. MARSCHALL}

\begin{abstract}
Many fishing methods and gear types used in coral reefs cause physical damage to the reef substratum. Only recently have monofilament fishing lines been recognized as a cause of coral damage and death. We assessed the extent of damage caused by monofilament fishing lines to the cauliflower coral ( Pocillopora meandrina) colonies in fished and adjacent unfished zones at seven sites in the main Hawaiian islands. We examined coral colonies for the presence or absence of fishing line and for the degree of damage (dead, no live coral surface; damaged, some dead coral surface; or intact, no dead coral surface) in nine $25-\mathrm{m}^{2}$ grids. The mean proportion of colonies entangled with fishing lines in fished zones ranged from 0.18 to 0.44 . The mean proportion of dead or damaged colonies was higher in fished than adjacent unfished zones, and there was a positive linear relationship between the proportion of colonies entangled with fishing lines and the proportion of dead or damaged colonies. These results indicate that monofilament fishing lines have a negative impact on the health and survival of P. meandrina colonies. Because tourism and related recreational fishing activities are expanding rapidly in many tropical states and nations, we recommend that the degrading effects of fishing lines on corals be considered in the design and management of tourism development.
\end{abstract}

Key Words: coral damage, coral-reef conservation, monofilament fishing lines, Pocillopora meandrina, shore fishing

Daño a Coral Coliflor por Líneas de Pesca de Monofilamento en Hawai

Resumen: Muchos métodos y tipos de equipo de pesca utilizados en arrecifes de coral causan daño físico al sustrato del arrecife. El reconocimiento de las líneas de pesca de monofilamento como una causa de daño y muerte de corales es reciente. Evaluamos la extensión del daño por líneas de monofilamento en el colonias de coral coliflor (Pocillopora meandrina) en zonas de pesca adyacentes a zonas sin pesca en siete sitios en las islas de Hawaii. Examinamos la presencia o ausencia de líneas de pesca y el grado de daño (muerto, sin superficie de coral vivo; dañado, algo de coral muerto en la superficie; o intacto, sin coral muerto en la superficie) en colonias de coral en nueve parcelas de $25 \mathrm{~m}^{2}$. La proporción media de colonias enredadas con líneas de pesca en zonas de pesca varió de 0.18 a 0.44. La proporción media de colonias muertas o dañadas fue mayor en zonas de pesca que en zonas sin pesca adyacentes, y hubo una relación lineal positiva entre la proporción de colonias enredadas con líneas de pesca y la proporción de colonias muertas o dañadas. Estos resultados indicaron que las líneas de pesca de monofilamento tienen un impacto negativo sobre la salud y supervivencia de colonias de P. meandrina. Debido a 
la rápida expansión del turismo y de actividades de pesca recreativa en muchos estados y naciones tropicales, recomendamos que se consideren los efectos degradantes de líneas de pesca en corales cuando se diseñe y administre el desarrollo del turismo.

Palabras Clave: conservación de arrecifes de coral, daño a corales, líneas de pesca de monofilamento, pesca costera, Pocillopora meandrina

\section{Introduction}

Many of the fishing methods and gear types used to catch coral reef fishes cause direct physical damage to the reef substratum (Jennings \& Kaiser 1998). The destructive effects of drive-netting, dynamite and cyanide fishing, gill nets, fish traps, and anchors have been relatively well documented (Guard \& Masaiganah 1997; McManus et al. 1997; Edinger et al. 1998; Jennings \& Kaiser 1998; Jones \& Hoegh-Guldberg 1999). In contrast, only recently have monofilament fishing lines been recognized as a cause of coral damage and death (Bavestrello et al. 1997; Schleyer \& Tomalin 2000).

Cast-fishing lines are likely to abrade polyps and the upper tissue layers of corals. Shorefishing tackle also damages corals with lead sinkers and steel hooks. When lines become entangled in corals or catch corals by their sinkers and hooks, they are often cut off at the reel and left on the reef. In addition, when respooling a reel with new line, fishers reportedly discard old line by casting the used line from the shore (Rizzuto 1983). Cut lines are swept by surge action and become entangled in and abrade corals. Corals can recover from small lesions; when a damaged area is large or physical damage occurs frequently, however, recovery may be difficult (Bak et al. 1977; Bak \& Steward-van Es 1980).

It has been presumed that the effects of individual fishers are small, so damage to coral from monofilament fishing lines has not been well documented. However, tourism and related recreational fishing activities are expanding rapidly in many tropical states and nations (U.S. Department of State 1998; White et al. 2000; Yap 2001). The combined effects of the activities of sport fishers can be considerable, and they necessitate immediate assessment of the extent of coral damage caused by pole and line sport fishing.

Fiberglass rods with either spinning or conventional reels spooled with monofilament line are the most popular gear used for coastal sport fishing in Hawaii (Rizzuto 1983). Yoshikawa and Asoh (2004) have reported a high incidence of cauliflower coral (Pocillopora meandrina) colonies becoming entangled with fishing lines and its association with a high incidence of dead colonies at a single fishing site in Oahu, Hawaii. We expanded their study and assessed the extent of damage inflicted by monofilament fishing lines on cauliflower coral colonies at major fishing sites on the islands of Oahu, Maui, and Hawaii. Pocillopora meandrina forms compact branching colonies on hard substrate. It thrives in high-energy environments and is the predominant coral species at popular fishing sites in the main Hawaiian Islands, usually accounting for $>90 \%$ of total coral cover on the reefs.

\section{Methods}

We assessed the extent of damage by monofilament fishing lines to $P$. meandrina from June to August 2002 in a fished and an adjacent unfished zone at seven sites: two sites in Oahu (Kewalo and Portlock), two sites in Maui (Scenic Lookout and Hanamanioa Point), and three sites in Hawaii (Keahole, Kealakekua, and South Kona). Information on the location of major 
fishing sites and a map of a fished zone at each site were obtained from personnel of the State of Hawaii's Department of Land and Natural Resources. The seven study sites were selected based on their accessibility by boat or offshore scuba diving.

An unfished zone at each site was defined in an area adjacent to but outside the fished zone so as to minimize differences in environmental factors. Because some fishing is expected outside the fished zones where the majority of fishing occurs, our distinction between fished and unfished zones was relative, and unfished zones did not necessarily mean areas of absolutely no fishing. In Maui and Hawaii sites, unfished and fished zones were 5-7 $\mathrm{m}$ deep and were separated from each other by a distance of approximately $50 \mathrm{~m}$ along the shoreline. Fished zones in these sites pointed toward the sea, so adjacent unfished zones were situated along the more protected, concave extension of the shoreline from fished zones. In the two sites in Oahu, unfished areas along the shoreline were beyond the reach of shore diving. Therefore, we defined the unfished zone as an area directly offshore of the fished zone (70 m offshore and hence beyond the reach of most cast-fishing lines). The reef terrace extended without changing depth (2-3 $\mathrm{m}$ in Kewalo and 6-7 $\mathrm{m}$ in Portlock) up to the unfished zones at these sites.

All seven study locations were shore cast-fishing sites. Fishers reached the sites via land routes by car and on foot and threw lines from a basalt rock face above the water surface. Snorkeling, scuba diving, and anchoring by boats used in scuba diving were observed in some sites, but these activities were independent of the presence or absence of cast fishing. Snorkelers were frequently observed in both fished and unfished zones at Kewalo, Oahu. At Portlock, Oahu, fished and unfished zones were within the area of shore scuba diving, and the unfished zone was potentially an area of anchoring for boats used in scuba diving. Similarly, both fished and unfished zones at Scenic Lookout, Maui, were within the area of shore scuba diving, and sites at Keahole, Hawaii, were within the area of boat scuba diving.

We laid three 25-m transects lines, separated from one another by $5 \mathrm{~m}$, parallel to the shoreline within fished and adjacent unfished zones. Three $5 \times 5 \mathrm{~m}$ grids spaced $5 \mathrm{~m}$ apart were then placed along each 25-m transect. In the fished zone in Kealakekua, Hawaii, transect length was $15 \mathrm{~m}$ and the number of grids along a transect was two because of the small size of the fished area. Except for the unfished zones in the two sites in Oahu, transects were placed approximately $20 \mathrm{~m}$ from the shoreline.

We examined coral colonies within a grid for the presence or absence of fishing line and for the degree of damage (entirely dead, no live surface area; damaged, some part of the colony surface dead but some part still alive; or intact, no dead surface area). An area of coral surface was considered dead if it lacked live coral tissues or was covered with algal growth. Very old dead colonies that had lost colony shape through erosion were not included in the data. For each grid we calculated coral density (number of colonies per square meter), percentage of colonies entangled with fishing line, and percentage of entirely dead or damaged colonies.

After log-transforming the data, we compared mean coral densities between fished and unfished zones and among sites by split-plot-design analysis of variance (ANOVA), with zone (fixed factor), site (fixed factor), and transect (nested within site, random factor) as independent variables. We also compared the proportion of dead or damaged colonies between fished and unfished zones and among sites by ANOVA (split-plot design) with the same independent variables. The relationship between the proportion of coral colonies entangled with fishing lines and the proportion of dead or damaged colonies was analyzed by a general linear model, with the proportion of dead or damaged colonies as a dependent variable and the proportion of colonies entangled with fishing lines and site as independent variables. Because removal of fishing lines 
by scuba divers was indicated in Portlock in Oahu (D. Pence, personal communication), the data from this site were excluded from the latter analyses.

\section{Results}

The mean coral density ranged from $0.34 / \mathrm{m}^{2}$ in the fished zone in Kewalo, Oahu, to $5.36 / \mathrm{m}^{2}$ in the fished zone in Kealakekua, Hawaii (Fig. 1). There was a significant interaction between zone and site in coral density $(F=3.86, \mathrm{df}=6,95, p=0.002$; Table 1 ; Fig. 1$)$, in which the mean coral density was higher in unfished than fished zones in four sites but was higher in fished than unfished zones in the three remaining sites. In the full model including the interaction term, the main effect of site was significant $(F=33.24, \mathrm{df}=6,14, p<0.0001$; Table 1 ; Fig. 1$)$ but the main effect of zone was not significant $(F=1.49$, $\mathrm{df}=1,95, p=0.225$; Table 1 ; Fig. 1$)$.

The mean proportion of colonies entangled with fishing lines in fished zones ranged from 0.18 in South Kona, Hawaii, to 0.44 in Scenic Lookout, Maui (Fig. 2). Some lines were covered with crustose calcareous algae, whereas others lacked algal growth on their surface. A low degree of fishing-line entanglement in unfished zones was observed in all sites, with the mean proportion of colonies with fishing lines ranging from $<0.001(0.1 \%)$ in Portlock, Oahu, and Keahole, Hawaii, to about 0.02 (2\%) in the two sites in Maui.

Figure 1. Coral density in fished and unfished zones at seven study sites. Vertical lines at the top of bars indicate one standard error.

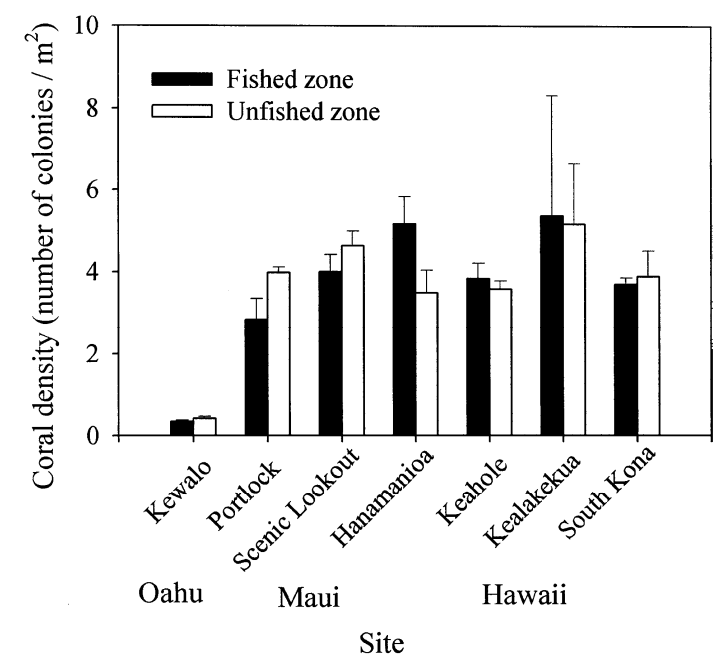

The proportion of dead or damaged colonies was greater in fished than unfished zones ( $F$ $=160.98, \mathrm{df}=1,95, p<0.0001)$ and differed between sites $(F=8.67, \mathrm{df}=6,14, p<0.0001)$. There was a significant interaction between zone and site in the proportion of dead or damaged colonies ( $F=3.92$, df $=6,95, p=0.002$; Table 1 ; Fig. 3 ), but the proportion of dead and damaged colonies was still higher in the fished than unfished zones.

The proportion of dead or damaged colonies increased with an increasing proportion of colonies entangled with fishing lines $(F=31.02$, $\mathrm{df}=1$,39, $p<0.0001$; Table 1$)$. Although site influenced the proportion of dead or damaged colonies $(F=4.75$, $\mathrm{df}=5,39, p=0.002)$, the interaction between site and proportion of colonies entangled with fishing lines was not significant $(F=0.53, \mathrm{df}=5,39, p=0.75)$, indicating that the six site-specific regression lines were parallel but differed in elevation. 


\begin{tabular}{lllllll}
\hline Dependent variable & Source of variation & $d f$ & Type III SS $^{a}$ & Type III MS $^{b}$ & $\mathrm{~F}$ & $\mathrm{p}$ \\
& & & & & & \\
\hline Coral density & site & 6 & 16.660 & 2.777 & 33.24 & $<0.0001$ \\
& zone & 1 & 0.020 & 0.020 & 1.49 & 0.225 \\
& site $\times$ zone & 6 & 0.310 & 0.052 & 3.86 & 0.002 \\
& transect (site) & 14 & 1.175 & 0.084 & 6.28 & $<0.0001$ \\
& error & 95 & 1.270 & 0.013 & & \\
& total & 122 & & & & \\
Proportion of dead or & site & 6 & 2.548 & 0.425 & 8.67 & $<0.0001$ \\
damaged coral & & & & & & \\
& zone & 1 & 1.214 & 1.214 & 160.98 & $<0.0001$ \\
& site $\times$ zone & 6 & 0.177 & 0.030 & 3.92 & 0.002 \\
& transect (site) & 14 & 0.689 & 0.049 & 6.52 & $<0.0001$ \\
& error & 95 & 0.717 & 0.008 & & \\
Proportion of dead or & total & 122 & & & & \\
damaged coral & line & 1 & 0.288 & 0.288 & 31.02 & $<0.0001$ \\
& site & 5 & 0.220 & 0.044 & 4.75 & 0.002 \\
& line $\times$ site & 5 & 0.025 & 0.005 & 0.53 & 0.752 \\
& error & 39 & 0.361 & 0.009 & & \\
\hline
\end{tabular}

Table 1. Analysis of variance results for coral density and proportion of dead or damaged colonies, and the result of the general linear model for the proportion of dead or damaged colonies.

${ }^{\mathrm{a}} \mathrm{SS}$, sum of squares.

${ }^{\mathrm{b}} \mathrm{MS}$, mean squares.

${ }^{\mathrm{c}}$ Proportion of colonies with fishing lines.

\section{Discussion}

The consistently higher proportion of dead or damaged colonies in a fished than an adjacent unfished zone in all sites and a positive correlation between the proportion of colonies entangled with fishing lines and the proportion of dead or damaged colonies in six of the seven sites indicate that monofilament fishing lines have a negative impact on the health and survival of $P$. meandrina colonies. These findings also suggest that degradation of corals by fishing lines, which was previously reported for a single site in Oahu (Yoshikawa \& Asoh 2004), is widespread among the popular cast-fishing sites in the main Hawaiian Islands.

The observed difference in the proportion of dead or damaged colonies between fished and unfished zones may have resulted from the consistent difference in microenvironments between the two zones over the sites. However, unfished zones were located in more exposed areas of the reef in some sites and in the more protected areas in others, and there was no consistent pattern in coral density between two zones over the sites. 
Figure 2. Proportion of coral colonies with fishing lines in fished and unfished zones at seven study sites. Vertical lines at the top of bars indicate one standard error.

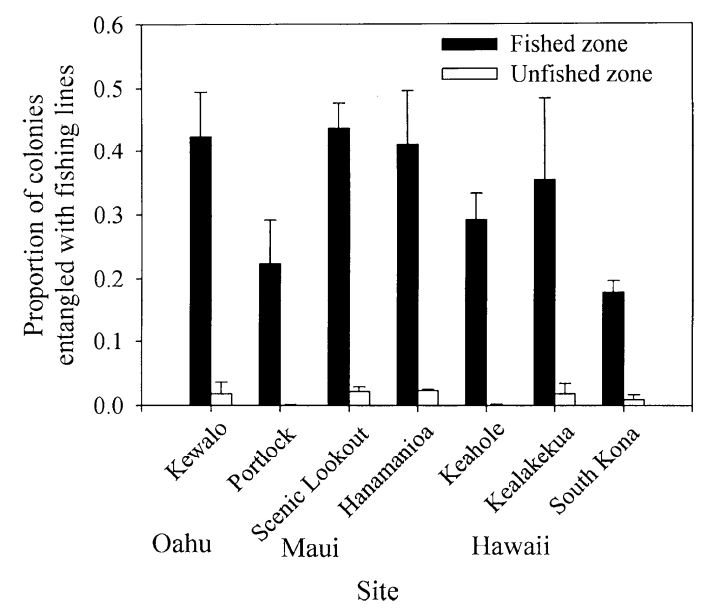

Figure 3. Proportion of dead or damaged colonies in fished and unfished zones at seven study sites. Vertical lines at the top of bars indicate one standard error.

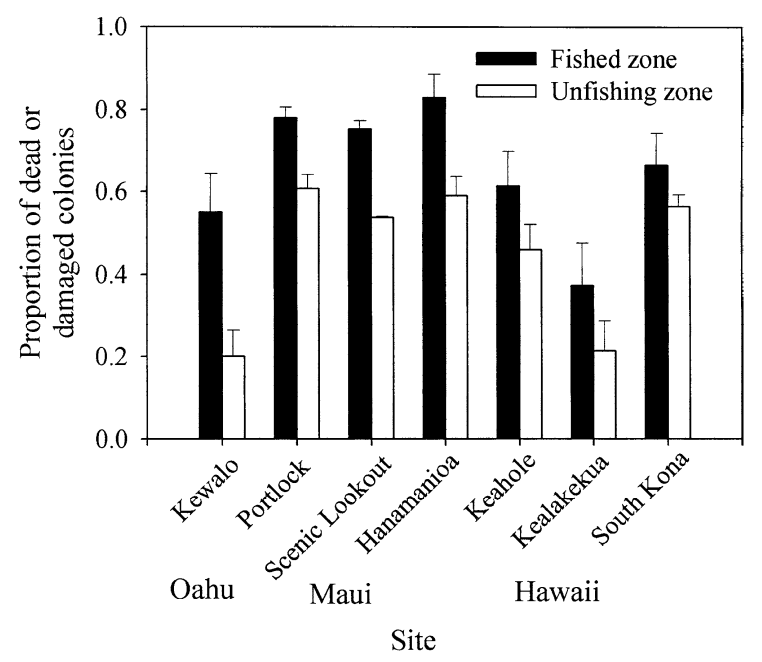

Still, we observed a consistently higher proportion of dead or damaged colonies in fished than unfished zones in all sites. This suggests that the observed difference between zones was mainly due to the presence or absence of fishing pressure rather than to differences in microenvironments. We did not take measurements of physical parameters, so the latter possibility cannot be entirely excluded.

Similarly, it might be argued that the observed difference in the proportion of dead or damaged colonies between zones is due to consistent differences in other human activities between zones in the sites. Neither boat anchoring nor tampering with corals by wading fishers was associated with fishing because fishers reached these sites by car and on foot and fished from rock faces above the water surface. In addition, there was no pattern in snorkeling and scuba-diving activities that paralleled the fished-unfished dichotomous zoning. Yet we observed consistently higher proportions of dead or damaged colonies in fished than unfished zones in all sites, suggesting that the observed difference between zones was due to differences in fishing pressure rather than to differences in other human activities.

In a similar survey conducted in 1999 at Kewalo, Oahu, Yoshikawa and Asoh (2004) 
found the proportion of colonies with fishing lines to be 0.65 ( 0.45 in the present study) and the proportion of dead or damaged colonies to be 0.8 ( 0.55 in the present study). Because of the low colony density at the site, however, the difference between the studies was not statistically significant ( $p>0.99$; heterogeneity testing of contingency tables; Zar 1984).

Each of the popular fishing sites typically covers a relatively small area, extending on the order of tens to hundreds of meters along the shoreline, and the efforts of recreational fishers are concentrated on popular fishing sites. Therefore, we would expect the effects of cast fishing to be characterized by two features: (1) small areas affected and (2) a high degree of damage within these small areas. The high incidence of fishing-line entanglement on $P$. meandrina colonies in fished zones but not in adjacent unfished zones in our study agrees with these contentions and suggests that seemingly small effects of individual fishers may accumulate over time to cause a significant negative impact on the health and survival of corals within fished zones. A similarly high incidence of damage by monofilament fishing lines within fished areas was reported in South African reefs (up to 60\% of reef organisms; Schleyer \& Tomalin 2000) and in the Mediterranean reefs of northeastern Italy (up to $40 \%$ of gorgonian colonies, Bavestrello et al. 1997).

The highly localized effects of cast fishing on coral health have important management implications. Because fishing lines are concentrated in relatively small areas, programs such as reef cleaning by divers may be economically feasible. To make these programs effective in reducing the impact of fishing lines and improving the health of corals, however, further studies are necessary. Studies on fishing intensity, degree of fishing-line entanglement, and rate of recovery of corals entangled with fishing line would provide important guidance for the design of reef-cleaning programs. Management actions that would reduce new incidents of line entanglement include fisher education, gear restrictions (e.g., limitations to the number of fishing poles allowed), and identification of designated fishing sites. For example, fisher education on fishing ethics and advertisement of fishing regulations through signs at fishing sites would not be costly if the number and area of fishing sites were limited.

In contrast to cast fishing, trolling probably has less of a locally concentrated effect. Lost and discarded lines from troll fishing probably are distributed in lower densities and over much larger areas than those from cast fishing, and programs such as reef cleaning may not be effective or economically feasible. Other management strategies, such as fisher education and gear limitation, would be more practical and effective than removal of fishing line.

Studies on the effects of fishing in coral reef areas have focused either on the effects of overfishing on coral reef community structures or on clearly destructive fishing methods such as drive netting and explosive and poison fishing (Bryant et al. 1998; Burke et al. 2002). Similarly, studies on the impacts of marine tourism activities have been centered on diving and snorkeling, anchoring, and boating, including boat grounding (Bryant et al. 1998). With tourism and related recreational fishing activities expanding rapidly in many tropical states and nations (U.S. Department of State 1998; White et al. 2000; Yap 2001), monofilament fishing lines should not be overlooked as a potential cause of reef destruction. We recommend that the degrading effects of fishing lines on reefs be considered in the design and management of tourism development.

\section{Acknowledgments}

For their help with the field data collection, we are deeply indebted to A. Clark, S. Hau, and R. Sparks at the Division of Aquatic Resources, Department of Land and Natural Resources, State of Hawai' $i$; D. Pence at the Diving Safety Office, University of Hawai'i at Manoa; and J. Mendez. We also thank J. Koontz for her help with data entry. This study was supported by a 
grant from the National Fisheries and Wildlife Foundation (2001-0336-002) to E.A.M.

\section{Literature Cited}

Bak, R. P. M., and Y. Steward-Van Es. 1980. Regeneration of superficial damage in the Scleractinian corals Agaricia agaricites f. purpurea and Porites astreoides. Bulletin of Marine Science 30:883-887.

Bak, R. P. M., J. J. W. M. Brouns, and F. M. L. Heys. 1977. Regeneration and aspects of spatial competition in the Scleractinian corals Agaricia agaricites and Montastrea annularis. Proceedings of the International Coral Reef Symposium 3:143-149.

Bavestrello, G., C. Cerrano, D. Zanzi, and R. Cattaneo-Vietti. 1997. Damage by fishing activities to the Gorgonian coral Paramuricea clavata in the Ligurian Sea. Aquatic Conservation: Marine and Freshwater Ecosystems 7:253-262.

Bryant, D., L. Burke, J. McManus, and M. Spalding. 1998. Reefs at risk: a map-based indicator of threats to the world's coral reefs. World Resources Institute, Washington, D.C.

Burke, L., L. Selig, and M. Spalding. 2002. Reefs at risk in Southeast Asia. World Resources Institute, Washington, D.C.

Edinger, E. N., J. Jompa, G. V. Limmon, W. Widjatmoko, and M. J. Risk. 1998. Reef degradation and coral biodiversity in Indonesia: effects of land-based pollution, destructive fishing practices and changes over time. Marine Pollution Bulletin 36:617-630.

Guard, M., and M. Masaiganah. 1997. Dynamite fishing in southern Tanzania, geographical variation, intensity of use and possible solutions. Marine Pollution Bulletin 34:758-762.

Jennings, S., and M. J. Kaiser. 1998. The effects of fishing on marine ecosystems. Advances in Marine Biology 34:201-352.

Jones, R. J., and O. Hoegh-Guldberg. 1999. Effects of cyanide on coral photosynthesis: implications for identifying the cause of coral bleaching and for assessing the environmental effects of cyanide fishing. Marine Ecology Progress Series 177: 83-91.

McManus, J. W., R. B. Reyes Jr., and C. L. Nañola Jr. 1997. Effects of some destructive fishing methods on coral cover and potential rates of recovery. Environmental Management 21:69-78.

Rizzuto, J. 1983. Fishing Hawaii style. Hawaii Fishing News Press, Honolulu.

Schleyer, M. H., and B. J. Tomalin. 2000. Damage on South African coral reefs and an assessment of their sustainable diving capacity using a fisheries approach. Bulletin of Marine Science 67:1025-1042.

U.S. Department of State. 1998. Coral reefs and tourism: the threat and the potential. Fact sheet. Bureau of Oceans and International Environmental and Scientific Affairs, U.S. Department of State, Washington, D.C.

White, A. T., H. G. Vogt, and T. Arin. 2000. Philippine coral reefs under threat: the economic losses caused by reef destruction. Marine Pollution Bulletin 40:598-605.

Yap, H. T. 2001. Another look at coral reef degradation. Marine Pollution Bulletin 42:527.

Yoshikawa, T., and K. Asoh. 2004. Entanglement of monofilament fishing lines and coral death. Biological Conservation 117:557-560.

Zar, J. H. 1984. Biostatistical analysis. 2nd edition. Prentice Hall, Englewood Cliffs, New Jersey. 